\title{
Dagmara PRYSTACKA
}

Uniwersytet im. Adama Mickiewicza, Poznań

\section{Zawód - żona polityka. Rola kobiet w kreowaniu wizerunku politycznego}

O statnie wybory prezydenckie, a w ślad za tym kadencja Aleksandra Kwaśniewskiego, codzienne życie polityczne i kolejna kampania prezydencka, wszystko to pokazuje nam, jak ważna stała się rola żony polityka. Żona jako prezes fundacji, jako doradca, jako przewodnicząca stowarzyszenia, jako działaczka na rzecz praw dzieci, a każde tego typu działanie - jako jeden z elementów wizerunku męża - polityka. Socjologowie i politolodzy zgodnie zauważaja, że niesłabnąca w sondażach społecznych popularność Aleksandra Kwaśniewskiego, to w głównej mierze zasługa jego żony - Jolanty ${ }^{1}$. Właśnie Jolanta Kwaśniewska wykreowała w Polsce nową rolę Pierwszej Damy - kobiety aktywnej, wspierającej swojego męża już od pierwszych dni kampanii wyborczej, osoby angażującej się w akcje społeczne, pokazującej się chętnie w środkach masowego komunikowania. Jej śladem, z lepszym i gorszym rezultatem, poszły żony innych polityków, między innymi żony premierów - Leszka Millera i Jerzego Buzka².

Podczas kampanii prezydenckiej w 2000 roku doszło do swoistej „,walki” między żonami kandydatów. Prasa, w szczególności kobieca, rozpisywała się na temat Jolanty Kwaśniewskiej, Marii Krzaklewskiej, Aleksandry Kalinowskiej, Ireny Olechowskiej. W publikacjach pytano czy „,̇ony okażą się tajną bronią mężów w zbliżających się wyborach?”. Zaglądano do ich domów, metryk, a nawet torebek; przeprowadzano z nimi liczne wywiady.

Kampania prezydencka żon również w roku 2005 poprzedzała wybory głowy państwa. Z cienia wyszły: Maria Kaczyńska, żona Marka Borowskiego, Małgorzata Tusk. Nie zawsze chętnie, ale „dla dobra męża” opo-

1 Niektóre sondaże wskazują wręcz, że gdyby Jolanta Kwaśniewska startowała w kolejnych wyborach prezydenckich, miałaby duże szanse na wygraną.

2 Zarówno Ludgarda Buzek jak i Aleksandra Miller zaangażowały się w działalność fundacji na rzecz dzieci chorych i dzieci wybitnie uzdolnionych. 
wiadają o jego pasjach i ambicjach oraz o ich wzajemnych relacjach. Jak głosi plotka krążąca po Platformie Obywatelskiej, jedną z przyczyn późnego ogłoszenia startu w wyborach Donalda Tuska była niechęć żony do roli Pierwszej Damy. Małgorzata Tusk zapewnia jednak, że ubieganie się męża o prezydenturę uznała za naturalne $e^{3}$.

Z całą pewnością można jednak stwierdzić, że styl wykreowany przez J. Kwaśniewską zmobilizował do działania żony innych kandydatów, które w wielu wypadkach dopiero przy okazji kampanii wyborczej ukazały się opinii publicznej. Dotąd nieznane i wręcz anonimowe stały się nagle ,wizytówką" i niezbędnym elementem całej gry wyborczej i wizerunku kandydata ${ }^{4}$.

Od pierwszych dni po wygranych wyborach, żona polityka powinna „znaleźć” swoje nowe miejsce. Jak wskazują wyniki badań przeprowadzonych przez Centrum Badania Opinii Społecznej (CBOS), najbardziej pożądaną działalnością żony prezydenta jest praca charytatywna i społeczna (42 procent respondentów opowiada się za takim udziałem Pierwszych Dam w życiu publicznym), 41 procent Polaków uważa, że żona prezydenta powinna być aktywna w życiu publicznym i działać samodzielnie. Za to aż 57 procent twierdzi, że Pierwsza Dama nie powinna angażować się w sprawy polityczne - jej rola winna ograniczać się do wspierania męża ${ }^{5}$. Natomiast tylko 6 procent chciałoby żeby małżonka głowy państwa pracowała zawodowo, zgodnie ze swoim wykształceniem i zainteresowaniami ${ }^{6}$.

Tylko od małżonki polityka zależy czy przyjmie ona rolę aktywnie działającej osoby, czy też jedynie rolę żony ,przy boku męża”. Jedne panie prowadzą własną działalność charytatywną i udzielają się w różnego rodzaju akcjach społecznych, inne pozostają w zaciszu domowym, a opinia publiczna zna je tylko z oficjalnych uroczystości; jeszcze inne pozostaja na swoich dotychczasowych stanowiskach, wykonując nadal swój zawód.

3 J. Cieśla, B. Mikołajewska, Kolega wszystkich kolegów, „Polityka” 22 (2506).

${ }^{4}$ Zdaniem Ziemowita Jacka Pietrzaka, na zawartość wizerunku kandydata składają się: geograficzne zakorzenienie kandydata, czyli miejsce jego urodzenia oraz obszar, gdzie wychowywał się i żył; odwołanie do wartości grupy; wykształcenie kandydata; powiązanie kandydata z jego partią; etniczność, rasa czy pochodzenie narodowe; wyznanie religijne; orientacja seksualna oraz zamożność.

5 Pytanie, na czym to wsparcie miałoby polegać. Wiele żon wspiera swoich mężów przygotowując im przemówienia, organizując spotkania, konferencje i rauty, uczestnicząc we wszystkim niczym alter ego.

6 Badania CBOS zostały opublikowane w „Życiu Warszawy” dnia 5 X 1996 roku, w artykule Obowiazki Pierwszej Damy: z dala od polityki. 
Dagmar Havlova zrezygnowała z kariery aktorki, podobnie jak Nancy Reagan, a Raisa Gorbaczowa porzuciła posadę wykładowcy na Uniwersytecie Leningradzkim ${ }^{7}$. Małżonka prezydenta Andrew Johnsona, Eliza tylko dwa razy w ciągu czterech lat zeszła na parter Białego Domu, by powitać gości. Żona Billa Clintona - Hilary robi karierę jako pani senator i niedawno opublikowała swoją biografię, natomiast obecna Pierwsza Dama Białego Domu - Laura Bush pokazuje się rzadko, pozostając zdecydowanie w cieniu męża ${ }^{8}$. J. Kwaśniewska dopiero jako pani prezydentowa zrezygnowała $\mathrm{z}$ pracy zawodowej. „Na początku kadencji postanowiłam trzymać się z dala od polityki i stać dwa kroki za mężem. Z pracy zrezygnowałam po zapoznaniu się z wynikami badań CBOS-u, z których wynikało, że Polacy nie chcą, żebym pracowała zawodowo" ". Teraz z powodzeniem prowadzi Fundację „Porozumienie bez barier”. Dla porównania, jej poprzedniczka, Danuta Wałęsa zdecydowanie odżegnywała się od aktywnego wspierania działań męża. W jednym z wywiadów wyjaśniała: „Wiele żon takich sławnych ludzi przejawia taką aktywność, są i na mnie naciski. Nie godzę się, nie zdołałabym temu podołać" ${ }^{10}$. D. Wałęsa w każdej wypowiedzi podkreślała, że jej miejsce jest w domu, przy dzieciach. Do tego stopnia odseparowała się od polityki, że nie zamieszkała z mężem w Pałacu Prezydenckim w Warszawie, lecz pozostała w Gdańsku.

7 D. Havlova była aktorką teatralną, N. Reagan - filmową, zagrała m.in. w filmie Shadow on the Wall i w The Doctor and the girl, natomiast żona M. Gorbaczowa wykładała ideologię marksizmu-leninizmu.

8 W maju 2005 roku wiele emocji wzbudziło „nagłe wyjście z cienia” Pani Prezydentowej, Laury Bush podczas spotkania z przedstawicielami mediów, polityki i show-biznesu. Wtedy to nagle Pierwsza Dama zaczęła dowcipkować z rodziny Bushów, opowiadając o swoim mężu, teściowej i o życiu Białego Domu, ocierając się o granice dobrego smaku. Jednak jak zauważyli specjaliści marketingu politycznego oraz publicyści, w wystapieniu Laury Bush nie było spontaniczności, a całość tego wystąpienia była starannie wyreżyserowana. Tekst przygotował Landon Parvin, znany od lat autor przemówień dla republikanów, który pisał m.in. dla Ronalda Reagana, Busha seniora i Arnolda Schwarzeneggera. Wiadomo bowiem, że Laura Bush ma 80-procentowe poparcie, czyli niemal dwukrotnie lepsze notowania u wyborców niż mąż, a nawet poprzednie żony prezydentów. A wystąpienie, które pokazały wszystkie główne stacje telewizyjne, i które zostało odnotowane w różnych gazetach było okazją do „polepszenia” sondaży i rankingów popularności Busha. Na podstawie notatki Pierwsza przy mężu, która ukazała się w „Pani”, nr 06(177) z czerwca 2005.

9 Wypowiedź pochodzi z publikacji Pojedynek pierwszych dam, „Pani”, wrzesień 2000 .

10 Cytat pochodzi z wywiadu W. Skulskiej Być żonq Lecha, „Przekrój”, 17 XII 1999. 
Elżbieta Płażyńska, żona Macieja Płażyńskiego często towarzyszy mężowi w służbowych wyjazdach, oficjalnych przyjęciach i uważa to wręcz za przyjemność. Pracuje jako sędzia wydziału cywilnego Sądu Rejonowego w Gdańsku. Maria Twardowska, żona Czesława Bieleckiego wie, że bywanie na bankietach, oficjalnych kolacjach, otwarciach i promocjach należy do obowiązków żony polityka. Z przyjemnością wyjeżdżała z mężem za granice dwa razy do roku na sesje Zgromadzenia Parlamentarnego NATO (na własny koszt, bo żony są przewidziane, ale nie finansowane). Jako projektant wnętrz jest właścicielem firmy projektowej Dom i Miasto ${ }^{11}$. Maria Kaczyńska, żona prezydenta Warszawy i kandydata na prezydenta RP w wyborach 2005, mówi, że często reprezentuje męża na premierach teatralnych, koncertach, w operze, a ,żeby Leszek mógł odnosić sukcesy polityczne, ja muszę jemu zorganizować infrastrukturę"12.

Podkreślając znaczenie żony prezydenta i polityka warto zauważyć, że rola jej nie jest nigdzie prawnie usankcjonowana. Protokół Dyplomatyczny Ministerstwa Spraw Zagranicznych tylko raz wspomina o małżonce prezydenta. Według protokołu małżonce prezydenta należny jest szacunek, a każdy dobrze wychowany obywatel uzna jej wyróżniające się miejsce w czasie wszystkich oficjalnych prywatnych przedsięwzięć. W kontaktach oficjalnych preferuje się miejsce po prawej stronie. Idąc w towarzystwie mężczyzny, kobieta, osoba starsza lub gość honorowy zawsze znajduje się po prawej stronie. Małżonka prezydenta pamięta jednak, że ma obok siebie pierwszą osobę w państwie i to jej właśnie przysługuje bardziej zaszczytne miejsce. Stąd też idzie i siedzi obok męża po lewej stronie ${ }^{13}$.

Dla porównania chciałabym w tym miejscu opisać rolę żony pracownika dyplomatycznego. Otóż żona dyplomaty uczestniczy razem z mężem w charakterze gościa w lampkach wina, koktajlach, obiadach, przedstawieniach teatralnych, bierze udział - jako gospodyni lub współgospodyni - w przyjęciach organizowanych przez własną misję dyplomatyczna, urządza śniadania, obiady, kawy w swoim mieszkaniu. W żadnym zawodzie żona nie jest tak bardzo włączona w służbową działalność męża. Polityka nie wchodzi w zakres bezpośrednich zainteresowań żony pracownika dyplomatycznego, obracając się jednak w różnych środowiskach, powinna orientować się w jej ogólnych założeniach. Kobieta nie angażuje się

11 Czesław Bielecki był przewodniczącym Sejmowej Komisji Spraw Zagranicznych w rządzie Jerzego Buzka.

12 A. Boćkowska, Miłość przyszła z czasem, „Pani”, nr 05(176), s. 45.

13 E. Pietkiewicz, Protokót dyplomatyczny, Warszawa 1998. 
w rozmowy na tematy polityczne, jest bardzo ostrożna w wypowiedziach, które mogą być opatrznie zrozumiane. Nie zajmując się sprawami politycznymi, wykazuje z zasady zainteresowanie problemami kulturalnymi, społecznymi i na te tematy często prowadzi rozmowy. Żona pracownika dyplomatycznego nie powinna krytykować kraju przyjmującego, wypowiadać ujemnych ocen o stosunkach $\mathrm{w}$ nim panujących ${ }^{14}$.

Porównując rzeczywiste funkcje, jakie pełni Pierwsza Dama z funkcjami, jakie w protokole ma zapisane małżonka dyplomaty, nie ma zasadniczych różnic. Jedyną różnicę stanowi fakt, że Pierwsza Dama nigdzie oficjalnie nie ma zapisanych swoich praw i obowiązków, a żona pracownika dyplomatycznego - owszem.

Oprócz zasad protokołu dyplomatycznego, osoba piastująca najwyższy urząd w państwie, wraz z małżonką, zobowiązana jest również do przestrzegania zasad ceremoniału dworskiego. Oczywiście ceremoniał dworski dotyczy tylko wizyt na dworach królewskich. „Przed wizytą pary królewskiej uczestniczyłam w spotkaniu w Ministerstwie Spraw Zagranicznych, dotyczącym ceremoniału dworskiego. Poinstruowano mnie w jaki sposób należy zwracać się do królowej, księcia i osób towarzyszących" - opowiadała w wywiadzie Jolanta Kwaśniewska ${ }^{15}$. Również jej poprzedniczka, Danuta Wałęsa, musiała opanować zasady oficjalnych spotkań. „Przed podróżą do Indii D. Wałęsowa otrzymała protokół dyplomatyczny Ministerstwa Spraw Zagranicznych - program organizacyjny wizyty. Wszyscy wiedzą, jakie miejsce mają zająć, jak się poruszać, który pojazd dla kogo jest przeznaczony, co wolno, a czego nie"16.

„Madame Nobody”, tak określa swoje miejsce w prawie Jolanta Kwaśniewska. „Żona prezydenta w Polsce nie ma żadnego aparatu do pomocy. To jest Madame Nobody - ma ochotę, to niech sobie coś robi, ale nikt jej nie pomoże. Nie ma żadnej formalnej struktury, która byłaby odpowiedzialna za kalendarz żony prezydenta, za jej spotkania, za jej wizyty u fryzjera czy kosmetyczki"'17.

O swojej roli „Madame Nobody” zdała sobie sprawę również Daniele Mitterand, która zaraz po wygraniu przez męża wyborów prezydenckich

14 E. Pietkiewicz, Protokół dyplomatyczny, Warszawa 1998.

15 J. Baran, Biuro w tóżku, „Kurier Podlaski”, 24-29 XII 1996.

16 L. Śnieg-Czaplewska, Byłam VIP-em, czyli z Pierwszq Damq w Indiach, „Twój Styl", 1 IV 1994.

17 Wypowiedź pochodzi z wywiadu, jaki autorka niniejszego artykułu przeprowadziła z J. Kwaśniewską w Pałacu Prezydenckim 16 stycznia 2001 roku. 
stwierdziła, że francuska konstytucja nie zna pojęcia „,pierwszej damy”, O tym, że małżonka głowy państwa powinna mieć zagwarantowane prawa wypowiadała się publicznie Dagmar Havlova. „Żona prezydenta powinna mieć pewne prawa zagwarantowane konstytucyjnie. Skoro na małżonkę nakłada się obowiązek wspólnego reprezentowania kraju, to powinno się jej gwarantować pewne przywileje, np. sekretarkę czy wręcz biuro ${ }^{19}$.

Tymczasem żadna konstytucja, żadna ustawa ani rozporządzenie, zarówno w Polsce, jak i na świecie nie zna uregulowań pozycji Pierwszej Damy. Nawet w Stanach Zjednoczonych, gdzie tradycja demokracji jest bardzo długa. Kiedy Pierwsza Dama pojawia się w jadalni oficjalnej czy w jakimkolwiek innym pomieszczeniu, nie odzywają się fanfary - rozbrzmiewają tylko wtedy, gdy towarzyszy małżonkowi. Żaden oficjalny dokument nie przedstawia rejestru jej obowiązków. Właściwie First Lady nie ma określonego statusu w urzędowym, oficjalnym Waszyngtonie. The Congressional Directory (publikowany od 1834 roku) oficjalny spis osobistości urzędowych w Waszyngtonie, do marca 1965 roku, w ogóle nie wymieniał żon prezydentów ${ }^{20}$. Utarł się natomiast niepisany zwyczaj, że w czasie uroczystości zaprzysiężenia swojego męża na prezydenta, trzyma ona w ręku Biblię, na ogół rodzinną, na którą przyrzeka prezydent elekt. W Ameryce mówi się żartobliwie, że pozycja żony prezydenta jest najwyższym, nieobieralnym, niepłatnym stanowiskiem. Żona prezydenta nie otrzymuje bowiem żadnego wynagrodzenia za swoją pracę.

Niektóre żony, np. Rossalynn Carter i Betty Ford, obie bardzo aktywne i zaangażowane w różne programy społeczne, publicznie popierały propozycję, aby żona prezydenta USA otrzymywała stałą pensję ${ }^{21}$. W 1964 roku kongresman Jamek G. Fulton z Pensylwanii przedstawił w Kongresie projekt rezolucji w sprawie ustanowienia pensji dla żony prezydenta, ale projekt przepadł i wszelkie próby powrotu do tej propozycji zakończyły się jak dotąd niepowodzeniem ${ }^{22}$.

Zresztą nie tylko w Stanach Zjednoczonych pojawiały się takie propozycje. Podczas spotkania z Jolantą Kwaśniewską, opowiedziała mi, że swego czasu pojawił się również taki pomysł w Polsce. Rozważano nie tylko kwestię stałego wynagrodzenia Pani Prezydentowej, ale również

18 B. Gaińska, Żona prezydenta, „Kobieta i życie”, 28 VI 1997.

19 P. Deresz, W rodzinie państwa Havlów, „Trybuna Śląska”, 9 XII 1997.

20 N. Reagan, Moja kolej, Katowice 1991.

21 L. Pastusiak, Panie Białego Domu, Warszawa 2000.

22 N. Reagan, Moja kolej, Katowice 1991. 
kwestię uregulowania prawnego pozycji jej biura, współpracowników, sztabu potrzebnego do wykonywania określonych obowiązków. Podobno propozycja ta trafić miała pod obrady Sejmu, ale wtedy do władzy doszła koalicja Akcji Wyborczej Solidarność z Unią Wolności i propozycja została odrzucona ${ }^{23}$.

Pomimo braku uregulowań prawnych, na nieistnienie „nieformalnego" sztabu nie mogą narzekać First Ladies w USA. Pomimo tego, że o Pierwszej Damie nie ma w Konstytucji ani słowa, dysponuje ona gronem najbliższych współpracowników, o czym świadczą wspomnienia i biografie. Lady Bird zdołała utworzyć zrąb najlepszego sztabu w historii biura Pierwszej Damy. Asystentką do spraw kulturalnych została Bess Abel. Funkcja rzeczniczki, a de facto szefowej biura, dostała się w ręce Liz Carpenter. Z czasem Liz zatrudniła w swoim biurze aż sześć pełnoetatowych asystentek. Bess Abel miała cztery podwładne, pomagające jej w organizacji życia towarzyskiego w Białym Domu. Kiedy Jackie Kennedy pierwsza zaangażowała szefową sekretariatu prasowego, historycy uznali ten fakt za bardzo poważny ${ }^{24}$.

Abigail Adams była politycznym doradcą męża, przez co zyskała pogardliwy przydomek „pani prezydent”, Helen Taft dzięki zakulisowym działaniom skłoniła Theodore’a Roosevelta, by wskazał jej męża na swego następcę; Edit Wilson prowadziła nieoficjalną prezydenturę po tym, jak jej mąż miał udar mózgu. Eleonora Roosevelt wywoływała polityczne burze, a Bess Truman starannie redagowała wszystkie przemówienia i listy Harry'ego ${ }^{25}$. Kilkadziesiąt lat wcześniej Pierwsza Dama nie miała żadnego sztabu. Polityków, w większości mężczyzn, wchodzących w skład administracji federalnej nie obchodziło czy będzie ona miała jakieś zajęcie. Zatem funkcje i znaczenie małżonek głów państw biorą się z utrwalonych zwyczajów.

Jolanta Kwaśniewska opowiedziała mi pewną anegdotę. Otóż swego czasu zaprosiła do Pałacu Prezydenckiego Hilary Clinton, która przywiozła ze sobą niespodziewanie cały sztab: kosmetyczek, wizażystek, specjalistów, rzeczników, stylistów. Nasza Pani Prezydentowa nie będąc przygotowaną na taką liczbę gości, musiała zorganizować dodatkowe pokoje.

23 Koalicja ta uformowała się po wyborach parlamentarnych, które odbyły się 21 września 1997 roku. Do wyborów przystapiły 22 komitety wyborcze, a frekwencja wyborcza wynosiła 47,93 procent, w tym Akcja Wyborcza Solidarność zdobyła procentowo 33,83 głosów, a Unia Wolności - 13,37.

24 M. Truman, Pierwsze Damy, kulisy Białego Domu, Warszawa 1997.

25 Badaniami roli pierwszych dam w historii USA zajmuje się Smithsonian Institution, znajduje się tam również Wystawa Pierwszych Dam. 
Dużo miejsca roli i pozycji Pierwszej Damy poświęca także w swej biografii Hillary Rodham Clinton ${ }^{26}$. Wraca wspomnieniami do roku 1978, kiedy Bill Clinton został gubernatorem stanu Arkansas. Wtedy zaczęły się naciski, by postępowała odpowiednio do swojej nowej pozycji. „Jako żona prokuratora generalnego mogłam sobie pozwolić na pewną niekonwencjonalność, ale jako pierwsza dama Arkansas znalazłam się na widoku publicznym. Po raz pierwszy zdałam sobie sprawę, że moje osobiste wybory mogą wpływać na przyszłość polityczną męża"27.

Hillary Clinton bardzo zaangażowała się w kampanię wyborczą swojego męża, biorąc na ten czas urlop bezpłatny ${ }^{28}$. Jednak po wygranych przez Billa Clintona wyborach na stanowisko prezydenta Stanów Zjednoczonych, zrezygnowała z pracy zawodowej i zaczęła kompletować personel biura pierwszej damy, równocześnie pomagając mężowi ${ }^{29}$. „Oboje głowiliśmy się, jak zdefiniować moją nową rolę - wspomina H. Clinton. Będę miała stanowisko, ale nie prawdziwą pracę. Jak pomóc mężowi i służyć krajowi, równocześnie nie tracąc własnej tożsamości?" ${ }^{30}$.

W tym samym miejscu H. Clinton pisze: „Nie ma podręcznika dla pierwszych dam. Kobieta obejmuje tę funkcję, bo mężczyzna za którego wyszła za mąż, zostaje prezydentem. Każda z moich poprzedniczek przynosiła do Białego Domu inny sposób bycia i inne oczekiwania, inne sympatie i antypatie, marzenia i wątpliwości. Każda na swój sposób definiowała rolę, która wynikała z jej zainteresowań i stylu, ale także z potrzeb męża, rodziny i kraju. Ja powinnam zrobić to samo i wzorem wszystkich poprzednich pierwszych dam zdecydować jak wykorzystać dane mi możliwości i jak spełnić tradycyjne obowiązki. Historycznie biorąc, rola pierwszej damy jest głównie symboliczna. Oczekuje się od niej, że będzie reprezentowała idealną i raczej mityczną koncepcję amerykańskiej kobiecości. Wiele poprzednich pierwszych dam było wybitnymi kobietami, ale ich rzeczywiste życiowe osiagnięcia pomijano, zapominano o nich lub wręcz

26 Wspomnienia Rodham Hillary Clinton, Tworzac historię, ukazały się nakładem Świata Książki w 2003 roku.

27 Warto w tym miejscu podkreślić również, że Hillary Clinton została wręcz zmuszona przez opinię publiczną do zmiany nazwiska na nazwisko męża. Do czasu wyborów gubernatora w stanie Arkansas posługiwała się nazwiskiem panieńskim Rodham. W 1982 roku zaczęła przedstawiać się jako Hillary Rodham Clinton.

28 H. Clinton pracowała w firmie adwokackiej.

29 Bill Clinton był prezydentem USA przez dwie kadencje w latach 1993-2001. Był 42 prezydentem USA, wygrywając w wyborach z George'm Bush'em.

30 H. Clinton, Tworzqc historie, Warszawa 2003, s. 115. 
spychano je w niepamięć"31. Krótko po wyborach, Bill Clinton stwierdził publicznie, że jego żona będzie miała poważniejsze zadania do spełnienia w Białym Domu niż tylko pełnienie roli gospodyni. „Hillary zasiądzie koło mnie w gabinecie - oświadczył. - Amerykańskie prawo zabrania głowie państwa przyznawania żonie stanowiska w rządzie. Nikt nie może jednak zabronić zasięgania jej rad. Przez ostatnich 20 lat Hillary uczestniczyła w każdej decyzji, którą podjąłem i nie widzę powodu, dlaczego teraz miałoby się coś zmienić" 32.

Dzisiaj wiemy już, że Hillary Clinton wybrała rolę aktywnej, działającej na różnych płaszczyznach First Lady. Ale nie była to tylko działalność charytatywna. Należy zwrócić bowiem uwagę, że jej aktywność obejmowała również sferę polityki, zarówno wewnętrznej, jak i zewnętrznej Stanów Zjednoczonych. H. Clinton brała udział między innymi w pracach zespołu do spraw reformy służby zdrowia, w trakcie których została mianowana przez swojego męża na przewodniczącego Prezydenckiego Zespołu do spraw Krajowego Systemu Ochrony Zdrowia ${ }^{33}$.

Pierwsza Dama USA reprezentowała również kraj na zewnątrz. W swoją pierwsza, dłuższą podróż zagraniczną bez i w zastępstwo prezydenta wyruszyła w marcu 1995 roku. Była to podróż oficjalna do pięciu krajów Azji Południowo-Wschodniej, trwająca dwanaście dni. Wcześniej H. Clinton reprezentowała Stany Zjednoczone na zorganizowanym przez ONZ Światowym Forum Rozwoju Społecznego w Kopenhadze ${ }^{34}$.

Po zakończonej kadencji męża, Hillary Clinton obrała własną drogę polityczną. Zasiada w Senacie USA, a niektóre źródła podaja, że przygotowuje się do startu $\mathrm{w}$ następnych wyborach prezydenckich.

Z powyższych przykładów wynika, że mimo braku oficjalnego miejsca w prawie i ustroju First Ladies dysponują mniej lub bardziej zorganizowanym sztabem współpracowników, włączając się tym samym w mniejszym lub większym stopniu w politykę.

Warto w tym miejscu wspomnieć o miejscu i roli Pierwszych Dam w ZSRR, a następnie w Rosji. W tym kraju „rewolucję” w pojmowaniu roli i pozycji małżonki głowy państwa wprowadziła Raisa Gorbaczow, żona Michaiła Gorbaczowa. Jako pierwsza zaczęła aktywnie uczestniczyć

31 Ibidem, s. 115-116.

32 Kronika kobiet, pod red. M. B. Michalika, Warszawa 1993.

33 Ibidem, s. 140. Warto dodać w tym miejscu również, że nominacja ta wywołała wiele kontrowersji, zarówno w samym Białym Domu, jak i w urzędach federalnych.

${ }^{34} \mathrm{Na}$ podstawie autobiografii $\mathrm{H}$. Clinton, Tworzac historię. 
w życiu kraju, towarzyszyła mężowi w podróżach, wyrażała swoje opinie w różnych gremiach, ubierała się u zachodnich projektantów. Trzeba tu zwrócić uwagę na fakt, że takie zachowania w komunistycznym kraju były nie tylko rewolucyjne, ale wręcz szokujące. Podczas oficjalnego przyjęcia, które odbywało się 8 marca 1979 roku Raisa jako małżonka świeżo mianowanego sekretarza Komitetu Centralnego złamała zasady „protokołu”. Zwyczajem było bowiem, że małżonki przywódców gromadziły się przy wejściu do sali, by witać zagranicznych gości. Raisa stanęła z boku, nie respektując obowiązującego porządku. Widząc to najpoważniejsze naruszenie kremlowskiego protokołu żona wpływowego członka partii, trzeciego po Breżniewie, wytknęła ją palcem, nakazując: pani miejsce jest tam, na końcu rzędu ${ }^{35}$ !

Raisa, nazywana cesarzową pierestrojki miała zawsze decydujące znaczenie dla Michaiła, który miał zwyczaj nieustannie zasięgać rad żony, ponadto jej postawa stała się determinująca w zmianie mentalności i zapoczątkowała w Rosji zmiany, które wielu ocenia jako nieodwracalne ${ }^{36}$.

Na pytanie, czy gdyby przed laty, decydując się na małżeństwo - wiedziały, że ich mąż zaangażuje się w politykę, zmieniłyby zdanie, odpowiadają „nie”. Są zadowolone z życia u boku polityka, choć w większości przyznają, że wiążą się z tym wyrzeczenia. Gdy dzieje się coś ważnego, wszystko musi zejść na drugi plan. A one wtedy muszą być cierpliwe, wytrwałe i mądre, bo tylko przyjmując taką postawę, mogą pozytywnie wpłynąć na wizerunek polityczny swoich mężów.

\section{Summary}

The most recent presidential election at the time of writing, the term of Aleksander Kwaśniewski, everyday political life and the recent presidential campaign have demonstrated how important the role of a politician's wife has become. That a wife may act as the president of a foundation, as an advisor, as a chair of an association, as an activist defending the rights of children and any related activity, is one of the elements of the image of the husband - a politician. When asked whether their decision to get married would have been different if they had known many years ago that their husband would become involved in politics, the answer is „No”. Women are satisfied living with a politician, although they generally admit that this requires sacrifice. When something important is happening, everything else has to be neglected. Then they have to be patient, persistent and wise, because only such an attitude can advantageously influence the political images of their husbands.

35 W. Fedorowski, Caryce, Warszawa 2002, s. 133.

${ }^{36}$ Ibidem, s. 128-135. 